\title{
Comparative study on the phenolic content, antioxidant properties and HPLC fingerprinting of the leaf extracts of Clerodendrum volubile P. Beauv
}

\author{
Olorunfemi R. Molehin ${ }^{1 *}$, Omotade I. Oloyede ${ }^{1}$, Aline A. Boligon ${ }^{2}$ \\ ${ }^{1}$ Department of Biochemistry, Faculty of Science, Ekiti State University Ado-Ekiti P.M.B.5363 Ado-Ekiti, Nigeria. \\ ${ }^{2}$ Departamento de Farmácia Industrial, Universidade Federal de Santa Maria, Santa Maria, CEP 97105-900, Brazil.
}

\section{ARTICLE INFO \\ Article history: \\ Received on: 18/01/2017 \\ Accepted on: 09/02/2017 \\ Available online: 30/03/2017}

\section{Key words:}

Clerodendrum volubile; Antioxidant; Scavenging activity, HPLC-DAD.

\begin{abstract}
The present study aimed to investigate the phenolic contents and antioxidant properties of the various leaf extracts (methanol, ethanol, ethyl acetate) of Clerodendrum volubile. The total phenol and total flavonoid contents of the extracts were determined. In vitro scavenging activities of the extracts were assessed against 1 , 1-diphenyl-2 picrylhydrazyl (DPPH), 2, 2-azinobis (3-ethylbenzo-thiazoline- 6-sulfonate (ABTS) radical scavenging ability. The reducing power ability and high-performance liquid chromatography-diode-array detector (HPLC-DAD) of the extracts were also determined. The results revealed that methanolic extract had the highest total phenol and total flavonoid contents in all the extracts. The methanol extract had the highest reducing power, DPPH and ABTS radicals scavenging activities, followed by ethanol and ethyl acetate extracts. The HPLC-DAD results revealed the presence of both phenolic acids (caffeic acid, gallic acid) and flavonoids (catechin, quercetin, rutin, quercitrin, kaempferol, luteolin, apigenin) as its major bioactive polyphenolics. The difference in scavenging potential of the extracts may be due to variation in the phytoconstituents extracted using various solvents. The result suggests that the methanol leaf extract of Clerodendrum volubile could serve as a potential source of antioxidants and can be explored as a therapeutic agent in free radical induced diseases.
\end{abstract}

\section{INTRODUCTION}

The generation of free radicals is necessary for any biochemical process and constitutes an essential part of aerobic life and metabolism (Tiwari, 2001). The continuous generation of these radicals is because of the body's normal use of oxygen such as respiration and some cell mediated immune functions. A dynamic balance exists between the amount of free radicals generated in the body and antioxidants to scavenge them and protect the body against their deleterious effects (Ramjith et al., 2013). Hence an imbalance between the generation of free radicals and the scavenging abilities of the antioxidants results in state called oxidative stress. Furthermore, oxidative stress has been linked to be the major culprit in the pathology of many

\footnotetext{
* Corresponding Author

Olorunfemi R Molehin, Department of Biochemistry, Faculty of Science, Ekiti State University Ado-Ekiti P.M.B.5363 Ado-Ekiti, Nigeria.

E-mail: molehin.olorunfemi@gmail.com
}

diseases for example carcinogenesis, cardiovascular diseases, rheumatoid arthritis, ulcerative colitis and neurological degenerative diseases (Adesanoye et al., 2012; Bhattacharyya et al., 2014). Several studies have reported on how to delay or prevent the onset of these diseases. The most feasible and practical way to fight against these degenerative diseases is by boosting the body's natural antioxidant defense system or by supplementing with dietary antioxidants. This could be achieved by higher consumption of vegetables and fruits which are rich in natural antioxidants, especially phenolics and flavonoids, hence the growing interest in research on plants and new plants with antioxidants ability and fit for human consumption ( $\mathrm{Gu}$ et al., 2014; Kasote et al., 2015; Molehin et al., 2014). Therefore in recent years, considerable attention has been shifted to towards identification, development and utilization of more effective antioxidants from natural sources with antioxidant ability that may be used for human consumption (Chu et al., 2002). 
White butterfly (Clerodendrum volubile $\mathrm{P}$. Beauv) is a climbing shrub of $3 \mathrm{~m}$ high that belong to the family of Verbenaceae. It is commonly grown in deciduous forests across Africa including Nigeria, Ghana and Seirra Leone (Burkill, 1985). In the southern part of Nigeria, which is highly dominated by the Ijaws, Urhobos and Itsekiris and Yoruba, it is well-known as a delicious green leafy vegetable that is consumed as food and in folklore medicine, the plant was found to be effective in treatment of arthritis, diabetes rheumatism, dropsy, swellings, oedema, and gout and is also used as an anti-abortifacient and sedative (Erukainure et al., 2011; Fred-Jaiyesimi and Adekoya 2012). Erukainure et al. (2011) reported the high nutritional value of the green leafy vegetables. In another study by Fred-Jaiyesimi and Adekoya (2012), the phytochemical screening reveal the presence of alkaloids, flavonoids, saponins, anthraquinone and cardiac glycoside. The leaf extracts of $C$. volubile has been shown to possess anti-inflammatory properties (Fred-Jaiyesimi and Adekoya 2012). Moreover, there is a dearth of information on the phenolic content, antioxidant, and chromatographic fingerprinting of the green leafy vegetable. Therefore, this study was planned to investigate the phenolic contents, antioxidant properties and chromatographic fingerprinting of various leaf extracts of $C$. volubile.

\section{MATERIALS AND METHODS}

\section{Sample collection}

Fresh leaves of $C$. volubile were purchased from Oja Oba Market in Akure Metropolis of Ondo State, Nigeria (Figure 1). Authentication of the plant was carried out by A.A. Sorunbge of the Department of Biology, Federal University of Technology, Akure (FUTA) Nigeria. The sample was deposited at the university herbarium with voucher no FUTA/BIO/0121.

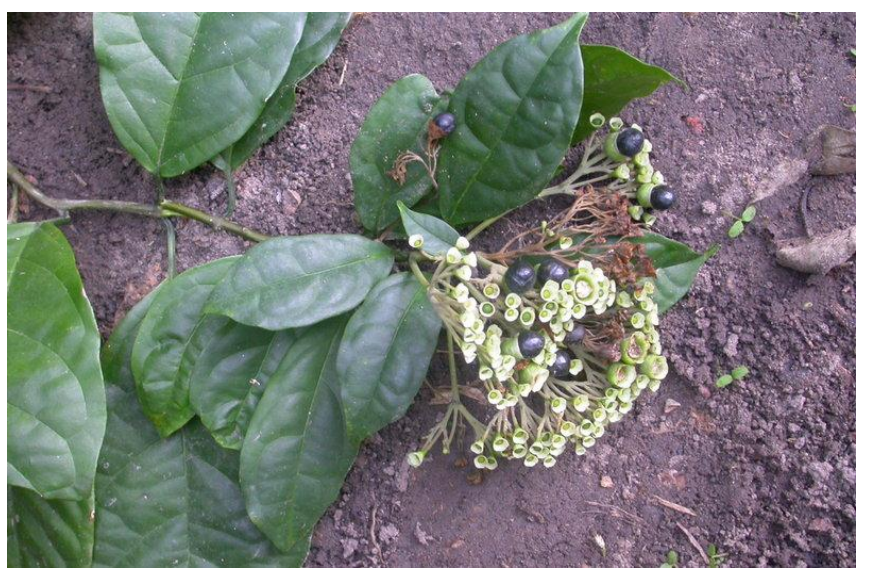

Fig. 1: Clerodendrum volubile.

\section{Chemicals and reagents}

All chemicals were of analytic grade, and glass-distilled water was used. 1, 1-diphenyl-2 picrylhydrazyl (DPPH), sodium trioxocarbonate (IV), aluminum (III) chloride, potassium acetate, 2,2-azinobis (3-ethylbenzo -thiazoline-6- sulfonate), sodiumnitroprusside, naphthylethylenediamine dihydrochloride, trichloroacetic acid, potassium acetate and potassium ferricyanide were sourced from BDH Chemicals Limited (Poole, England).

\section{Extraction of plant material}

Leaves of $C$. volubile $(30 \mathrm{~g})$ in powdered form were extracted with $200 \mathrm{~mL}$ of various organic solvents (methanol, ethanol, ethyl acetate) using shaker in $2000 \mathrm{r} / \mathrm{min}$ speed for $24 \mathrm{~h}$ at $37{ }^{\circ} \mathrm{C}$. The extracts were filtered with Whatman No. 1 filter paper for every $3 \mathrm{~h}$. Then, the collected extracts were evaporated to dryness under reduced pressure. The dried extracts were reconstituted in water and stored at $4{ }^{\circ} \mathrm{C}$ for further investigations.

\section{Determination of total phenol content}

The total phenol content was determined on the extracts using the method reported by Singleton et al. (1999). Appropriate dilutions of the extracts were oxidized with $2.5 \mathrm{~mL}$ of $10 \%$ FolinCiocalteau's reagent $(\mathrm{v} / \mathrm{v})$ and neutralized by $2.0 \mathrm{~mL}$ of $7.5 \%$ sodium carbonate. The reaction mixture was incubated for $40 \mathrm{~min}$ at $45{ }^{\circ} \mathrm{C}$ and the absorbance was measured at $765 \mathrm{~nm}$ in the spectrophotometer. The total phenol content was subsequently calculated using Gallic acid as standard.

\section{Determination of total flavonoid content}

The total flavonoid content of both extracts was determined using a slightly modified method reported by Meda et al. (2005). Briefly, $0.5 \mathrm{~mL}$ of appropriately diluted sample was mixed with $0.5 \mathrm{~mL}$ methanol, $50 \mu \mathrm{L}$ of $10 \% \mathrm{AlCl}_{3}, 50 \mu \mathrm{L}$ of $1 \mathrm{~mol} / \mathrm{L}^{-1}$ potassium acetate and $1.4 \mathrm{~mL}$ water, and allowed to incubate at room temperature for $30 \mathrm{~min}$. Thereafter, the absorbance of the reaction mixture was subsequently measured at $415 \mathrm{~nm}$. The total flavonoid was calculated using quercetin as standard.

\section{Quantification of Compounds by High Performance Liquid Chromatography-Diode-Array Detector}

C. volubile leaf (methanol, ethanol and ethyl acetate) extracts at a concentration of $12 \mathrm{mg} / \mathrm{mL}$ were analyzed for their phenolic constituents according to the method described by Adefegha et al. (2016) with slight modifications. The extracts were degassed in an ultrasonic bath. Qualitative-quantitative analyses using HPLC-diode-array detector (DAD) was performed with a Shimadzu Prominence Auto Sampler (SIL-20A) HPLC system (Shimadzu, Kyoto, Japan), equipped with Shimadzu LC20AT reciprocating pumps connected to a DGU 20A5 degasser with a CBM 20A integrator, SPD-M20A DAD and LC solution 1.22 SP1 software. Reverse phase chromatographic analyses were carried out under gradient conditions using $\mathrm{C}_{18}$ column $(4.6 \mathrm{~mm} \mathrm{x}$ $150 \mathrm{~mm}$ ) packed with $5 \mu \mathrm{m}$ diameter particles; the mobile phase was water containing $2 \%$ acetic acid (A) and methanol (B), and the composition gradient was: $5 \%$ of B until 2 min and changed to obtain $25 \%, 40 \%, 50 \%, 60 \%, 70 \%$ and $100 \% \mathrm{~B}$ at $10,20,30,40$, 50 and $80 \mathrm{~min}$, respectively according to the method described by 
Adefegha et al. (2014). The presence of nine antioxidants compounds was investigated, namely, gallic acid, caffeic acid, catechin, quercetin, quercitrin, rutin, kaempferol, luteolin and apigenin. Identification of these compounds was performed by comparing their retention time and UV absorption spectrum with those of the commercial standards. The flow rate was 0.6 $\mathrm{mLmin}^{-1}$, injection volume $50 \mu \mathrm{l}$ and the wavelength were $270 \mathrm{~nm}$ for gallic acid, $281 \mathrm{~nm}$ for catechin, $327 \mathrm{~nm}$ for caffeic acid, 365 $\mathrm{nm}$ for quercetin, quercitrin, kaempferol, rutin, apigenin and luteolin. The samples and mobile phase were filtered through 0.45 $\mu \mathrm{m}$ membrane filter (Millipore) and then degassed by ultrasonic bath prior to use. Stock solutions of standards references were prepared in the HPLC mobile phase at a concentration range of $0.030-0.250 \mathrm{mg} / \mathrm{ml}$ for catechin, quercetin, quercitrin, rutin, kaempferol, apigenin and luteolin; and $0.050-0.300 \mathrm{mg} / \mathrm{ml}$ for caffeic and gallic acids. The chromatography peaks were confirmed by comparing its retention time with those of reference standards and by DAD spectra (200 to $500 \mathrm{~nm})$. All chromatography operations were carried out at ambient temperature and in triplicate. The limit of detection (LOD) and limit of quantification (LOQ) were calculated based on the standard deviation of the responses and the slope using three independent analytical curves, as defined by Barbosa et al. (2014) LOD and LOQ were calculated as 3.3 and $10 \mathrm{\sigma} / \mathrm{S}$, respectively, where $\sigma$ is the standard deviation of the response and $\mathrm{S}$ is the slope of the calibration curve

\section{DPPH free radical scavenging ability}

The free radical scavenging ability of the extracts against DPPH (1,1-diphenyl-2 picrylhydrazyl) free radical was evaluated as described by Gyamfi et al. (1999). Briefly, an appropriate dilution of the extracts $(1 \mathrm{~mL})$ was mixed with $1 \mathrm{~mL}$ of 0.4 mmolL-1 methanolic solution containing DPPH radicals. The mixture was left in the dark for 30min and the absorbance was measured at $516 \mathrm{~nm}$. The DPPH free radical scavenging ability was subsequently calculated with respect to the reference (which contains all the reagents without the test sample).

\section{2, 2- azinobis (3-ethylbenzo-thiazoline- 6-sulfonate (ABTS) radical scavenging ability}

The $\mathrm{ABTS}^{\bullet}$ scavenging ability of the extracts was determined according to the method described by Re et al. (1999). $\mathrm{ABTS}^{\bullet}$ was generated by reacting an ABTS aqueous solution (7 mmol L $\left.{ }^{-1}\right)$ with $\mathrm{K}_{2} \mathrm{~S}_{2} \mathrm{O}_{8}\left(2.45 \mathrm{mmol} \mathrm{L}^{-1}\right.$, final concentration) in the dark for $16 \mathrm{~h}$ and adjusting the Abs $734 \mathrm{~nm}$ to 0.700 with ethanol. $0.2 \mathrm{~mL}$ of appropriate dilution of the extract was added to $2.0 \mathrm{~mL}$ ABTS* solution and the absorbance were measured at $734 \mathrm{~nm}$ after 15 min. The trolox equivalent antioxidant capacity was subsequently calculated.

\section{Determination of reducing property}

The reducing property of the extracts was determined by assessing the ability of the extract to reduce $\mathrm{FeCl}_{3}$ solution as described by Oyaizu (Oyaizu, 1986). A $2.5 \mathrm{~mL}$ aliquot was mixed with $2.5 \mathrm{~mL}$ of $200 \mathrm{mmol} \mathrm{L}^{-1}$ sodium phosphate buffer ( $\mathrm{pH} \mathrm{6.6)} \mathrm{and}$ $2.5 \mathrm{~mL}$ of $1 \%$ potassium ferricyanide. The mixture was incubated at $50{ }^{\circ} \mathrm{C}$ for $20 \mathrm{~min}$ and then $2.5 \mathrm{~mL}$ of $10 \%$ trichloroacetic acid was added. This mixture was centrifuged at $650 \mathrm{rpm}$ for $10 \mathrm{~min} .5 \mathrm{~mL}$ of the supernatant was mixed with an equal volume of water and $1 \mathrm{~mL}$ of $0.1 \%$ ferric chloride. The absorbance was measured at 700 $\mathrm{nm}$. The ferric reducing antioxidant property was subsequently calculated using ascorbic acid as standard.

\section{Statistical analysis}

Results of triplicate experiments were pooled and expressed as mean \pm SD. Means were compared using one-way analysis of variance and the least significance difference test. A statistically significant difference was accepted at $\mathrm{P}<0.05$ (Zar, 1984).

\section{RESULTS AND DISCUSSION}

It is well established that plants contain many phenolic compounds which possess a hydroxyl group moiety on their aromatic ring. These phenolic compounds break chain oxidation reactions by donating a hydrogen atom or chelating metals thus acting as reducing agents and antioxidants (Eghdami and Sadegh 2010; Pavithra and Vadivukkarasi 2015). Table 1 shows the total phenol and total flavonoid contents of all the extracts of $C$. volubile methanol, ethanol and ethyl acetate respectively. It was observed that methanol $[4.92 \pm 0.2 \mathrm{mgGAE} / \mathrm{g}$ gallic acid equivalent $(\mathrm{GAE}) / \mathrm{g}$ ] had significantly $(\mathrm{P}<0.05)$ higher total phenol contents than ethanol $(3.48 \pm 0.1 \mathrm{mg}$ GAE$/ \mathrm{g})$ and ethyl acetate $(2.63 \pm 0.2 \mathrm{mg} \mathrm{GAE} / \mathrm{g})$ extracts. Similarly, the total flavonoid content of methanol $(2.25 \pm 0.3 \mathrm{mg} \mathrm{QE} / \mathrm{g} \mathrm{mg}$ quercetin equivalent $(\mathrm{QE}) / \mathrm{g})$ was higher than those of ethanol $(2.15 \pm 0.2 \mathrm{mg}$ $\mathrm{QE} / \mathrm{g})$ and ethyl acetate $(2.04 \pm 0.1 \mathrm{mg} \mathrm{QE} / \mathrm{g})$ extracts but not significantly $(\mathrm{P}>0.05)$ different. The observed trend of results on total phenol and total flavonoid contents as shown in table 1 agrees with several reports on tropical vegetables with similar trends between the total phenol and flavonoid contents (Adefegha and Oboh, 2011; Eghdami and Sadegh, 2010; Kasote et al., 2015; Molehin and Adefegha, 2014; Pavithra and Vadivukkarasi, 2015).

Phenolic compounds are secondary metabolites found in plants and have been linked to several health benefits including antioxidant, antiglycemic, antibacterial, anti-inflammatory antiviral, vasodilator and anticarcinogenic properties (Adefegha et al., 2016; Duthie et al., 2000; Oboh et al., 2015; Rice-Evans and Miller 1997; Pereira et al., 2009; Sultan and Anwar 2009). Using the HPLC-DAD analytical assay, it was possible detect and confirm the presence of the some phenolic compounds in the extracts of $C$. volubile leaf. The HPLC-DAD chromatograms of the extracts are presented in Figures 3-5. As shown in Table 2, the result revealed the presence of both phenolic acids (caffeic acid, gallic acid) and flavonoids (catechin , quercetin, rutin, quercitrin, kaempferol, luteolin, apigenin).The extracts (methanol, ethanol and ethyl acetate) contained high amounts of quercetin, $[(15.34 \pm$ $0.01 \mathrm{mg} / \mathrm{g}, 15.02 \pm 0.01 \mathrm{mg} / \mathrm{g}$ and $13.27 \pm 0.01$ ) quercitrin 
$(8.72 \pm 0.02 \mathrm{mg} / \mathrm{g}, \quad 9.14 \pm 0.03 \mathrm{mg} / \mathrm{g}$ and $5.01 \pm 0.03 \mathrm{mg} / \mathrm{g})]$ respectively as its major phenolic compounds. Ethanolic extract had a higher significant $(\mathrm{P}<0.05)$ difference when compared with the methanolic extract $(8.59 \pm 0.01 \mathrm{mg} / \mathrm{g})$ and ethyl acetate extract $(9.02 \pm 0.01 \mathrm{mg} / \mathrm{g})$.

Furthermore, the leaf extracts also had a high amounts of quercetin luteolin, apigenin and kaempferol (Table 2) Presence of quercetin observed in the leaves extracts of $C$. volubile (table 2) may be partly linked to the antioxidant effects of the leaf extracts (Mattila and Hellstrom 2006). Quercetin, which was also identified in all the leaf extracts has been shown to possess the antiviral, antibacterial, anticarcinogenic and anti-inflammatory effects (Aline et al., 2013; Hemalatha et al., 2016; Sultan and Anwar 2009; Wagner et al., 2006). It is also a strong antioxidant because of its ability to scavenge free radicals and bind transition metal ions (Aline et al., 2013; Scalbert et al., 2005).

Quercitrin are found in many medicinal species of the plant e.g Melissa officinalis, Cymbopogon citratus (Pereira et al., 2009; Wagner et al., 2006). The phenolic compounds found in the leaf extracts has been reported to be powerful antioxidants present in vegetables and fruit (Guyot et al., 2009; Ogunwa et al., 2016; Wong-Paz et al., 2015) and known as take part of the mechanism of defense environmental in vegetables, fruit and herbs (Moure et $a l ., 2001)$. Then, it was presumed that the antioxidant activity in $C$. volubile leaf extracts could be due to those typical phenolics. $C$. volubile may represent a good source of important phenolic phytochemicals which may enhance good health and protect against diseases in humans and animals.

Several in vitro model systems have been used for determining the scavenging activity in various leaf extracts of $C$. volubile. DPPH is a stable nitrogen-centered free radical commonly used for testing radical scavenging activity of the compound or plant extracts. When the stable DPPH radical accepts an electron from the antioxidant compound, the violet color of the DPPH radical was reduced to yellow colored diphenylpicryl hydrazine radical which was measured colorimetrically. Substances which are able to perform this reaction can be considered as antioxidants and therefore radical scavengers (Adefegha et al., 2016). DPPH radical scavenging activity of various leaf extracts of $C$. volubile was presented in Figure 2. All the extracts scavenged DPPH radicals in the range of the concentration $(0.42-1.67 \mathrm{mg} / \mathrm{ml})$. All the extracts scavenged DPPH radicals in the range of the concentration $(0.42-1.67$ $\mathrm{mg} / \mathrm{ml}$ ) and the $\mathrm{EC}_{50}$ value of methanol, ethanol and ethyl acetate was found to be $1.7,2.0$ and $2.3 \mathrm{mg} / \mathrm{mL}$ respectively. Methanol exhibited strongest DPPH radical scavenging activity when compared to other extracts. The extracts radical scavenging activity were effective in the order methanol > ethanol > ethyl acetate. Antioxidant activity in the extracts was also investigated using the well-known ABTS method. The ABTS assay as shown in table 1 revealed that all the solvent extracts quenched ABTS radical and there was significant $(\mathrm{P}<0.05)$ difference between the solvent extracts in terms of ABTS free radical-scavenging. The extracts radical scavenging activity were effective in the order methanol > ethanol > ethyl acetate. The actions of the extracts against ABTS and DPPH radicals indicate that the vegetable species are good scavengers of radicals. The pattern of the extracts scavenging ability in ABTS assay is similar to that observed in DPPH assay. Furthermore, reducing powers of extracts were assessed based on their ability to reduce $\mathrm{Fe}^{3+}$ to $\mathrm{Fe}^{2+}$ and the results are presented in table 1 as ascorbic acid equivalent. It is noteworthy that the antioxidant capacity of these vegetable species as typified by their free radical-scavenging and reductive abilities in relation to their phenolic composition may indicate their potential roles in disease prevention and health promotion. This study agrees with the assertion that plants that are rich in phenolics play crucial roles in scavenging free radicals, quenching singlet and triplet oxygen, or decomposing peroxides (Dehpour et al., 2009; Meir et al., 1995; Ogunwa et al., 2016; Re et al., 1999; Salas et al., 2010).

Table 1: The total phenol, total flavonoid contents, ABTS radical scavenging ability and reducing property of C. volubile leaves extracts.

\begin{tabular}{cccc}
\hline Parameter (Unit) & methanol extract & ethanol extract & ethyl acetate extract \\
\hline Total Phenol (mgGAE/g) & $4.92 \pm 0.2^{\mathrm{a}}$ & $3.48 \pm 0.1^{\mathrm{b}}$ & $2.63 \pm 0.2^{\mathrm{c}}$ \\
Total flavonoid (mgQUE/g & $2.25 \pm 0.3^{\mathrm{a}}$ & $2.15 \pm 0.2^{\mathrm{a}}$ & $2.04 \pm 0.1^{\mathrm{a}}$ \\
ABTS ((mmol TEAC/g) & $0.000082 \pm 0.003^{\mathrm{a}}$ & $0.000060 \pm 0.002^{\mathrm{b}}$ & $0.000044 \pm 0.001^{\mathrm{c}}$ \\
Reducing property (mgAAE/g) & $2.65 \pm 0.21^{\mathrm{a}}$ & $1.57 \pm 0.15^{\mathrm{b}}$ & $1.41 \pm 0.07^{\mathrm{b}}$ \\
\hline
\end{tabular}

Values represent means \pm standard deviation of triplicate readings. Values with same superscripts are not significantly different at $\mathrm{P}>0.05$.

ABTS , 2,2'-azinobis-3-ethylbenzo-thiazoline-6-sulfonate ; GAE, garlic acid equivalent; TEAC, Trolox-equivalent antioxidant capacity; QUE, quercetin equivalent

Table 2: Phenolic Composition of Clerodendrum volubile (methanol, ethanol, ethyl acetate) extracts.

\begin{tabular}{|c|c|c|c|c|c|}
\hline \multirow{2}{*}{ Compounds } & \multicolumn{3}{|c|}{ Clerodendrum volubile } & \multirow{2}{*}{$\begin{array}{c}\text { LOD } \\
\mu \mathrm{g} / \mathrm{mL}\end{array}$} & \multirow{2}{*}{$\frac{\mathrm{LOQ}}{\mu \mathrm{g} / \mathrm{mL}}$} \\
\hline & Methanol $(\mathrm{mg} / \mathrm{g})$ & Ethanol $(\mathrm{mg} / \mathrm{g})$ & Ethyl acetate $(\mathrm{mg} / \mathrm{g})$ & & \\
\hline Gallic acid & $3.49 \pm 0.01^{\mathrm{a}}$ & $3.45 \pm 0.03^{\mathrm{a}}$ & $2.03 \pm 0.01 \mathrm{a}$ & 0.024 & 0.079 \\
\hline Catechin & $1.85 \pm 0.01^{\mathrm{b}}$ & $1.92 \pm 0.02^{\mathrm{b}}$ & $0.61 \pm 0.02^{\mathrm{b}}$ & 0.009 & 0.034 \\
\hline Caffeic acid & $3.56 \pm 0.03^{\mathrm{a}}$ & $1.93 \pm 0.01^{\mathrm{b}}$ & $6.74 \pm 0.02^{\mathrm{c}}$ & 0.015 & 0.050 \\
\hline Rutin & $3.19 \pm 0.01^{\mathrm{a}}$ & $3.57 \pm 0.01^{\mathrm{a}}$ & $8.95 \pm 0.01^{\mathrm{d}}$ & 0.018 & 0.062 \\
\hline Quercitrin & $8.72 \pm 0.02^{\mathrm{c}}$ & $9.14 \pm 0.03^{\mathrm{c}}$ & $5.01 \pm 0.03^{\mathrm{e}}$ & 0.011 & 0.037 \\
\hline Quercetin & $15.34 \pm 0.01^{\mathrm{d}}$ & $15.02 \pm 0.01^{\mathrm{d}}$ & $13.27 \pm 0.01^{\mathrm{f}}$ & 0.029 & 0.096 \\
\hline Kaempferol & $11.62 \pm 0.03^{\mathrm{e}}$ & $5.83 \pm 0.02^{\mathrm{e}}$ & $8.98 \pm 0.02^{\mathrm{d}}$ & 0.023 & 0.075 \\
\hline Luteolin & $8.59 \pm 0.01^{\mathrm{c}}$ & $11.49 \pm 0.01^{\mathrm{f}}$ & $9.02 \pm 0.01^{\mathrm{d}}$ & 0.014 & 0.046 \\
\hline Apigenin & $8.83 \pm 0.01^{\mathrm{c}}$ & $5.98 \pm 0.03^{\mathrm{e}}$ & $6.67 \pm 0.02^{\mathrm{c}}$ & 0.008 & 0.027 \\
\hline
\end{tabular}

Results are expressed as mean \pm standard deviations (SD) of three determinations.

Averages followed by different letters differ by Tukey test at $p<0.05$. LOD; limit of detection LOQ: limit of quantification 


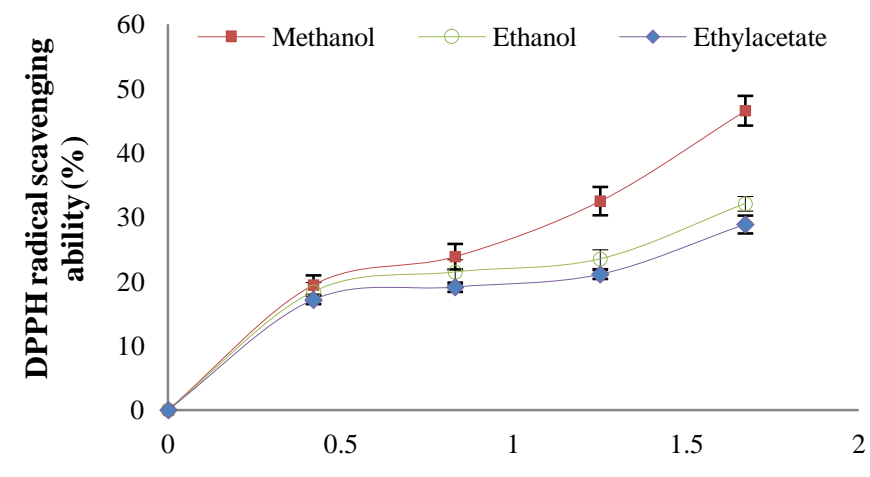

Concentration of extracts $(\mathrm{mg} / \mathrm{ml})$

Fig. 2: 1, 1-Diphenyl-2 Picrylhydrazyl (DPPH) free radical-scavenging ability of $C$. volubile extracts. Values represent mean \pm standard deviation of triplicate experiments.

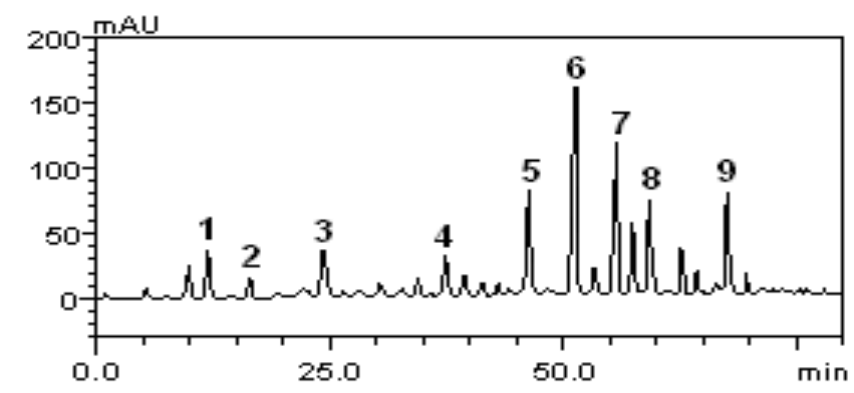

Fig. 3: Representative high performance liquid chromatography profile of methanolic extract of C. volubile. Gallic acid (peak 1), catechin (peak 2), caffeic acid (peak 3), rutin (peak 4), quercitrin (peak 5), quercetin (peak 6), kaempferol (peak 7), luteolin (peak 8) and apigenin (peak 9).

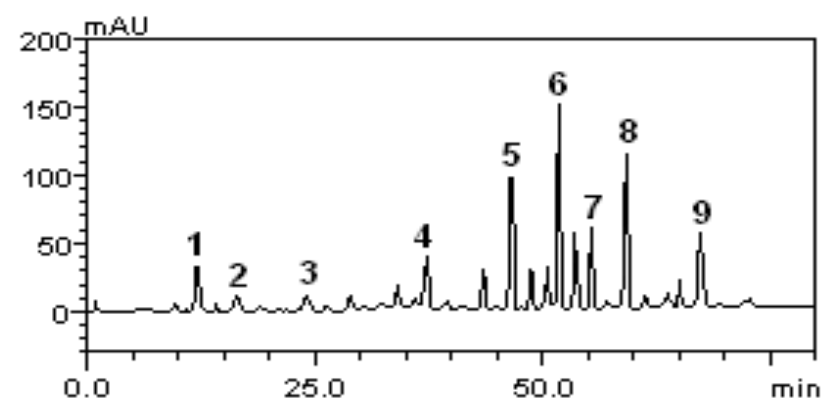

Fig. 4: Representative high performance liquid chromatography profile of ethanolic extract of $C$. volubile. Gallic acid (peak 1), catechin (peak 2), caffeic acid (peak 3), rutin (peak 4), quercitrin (peak 5), quercetin (peak 6), kaempferol (peak 7), luteolin (peak 8) and apigenin (peak 9).

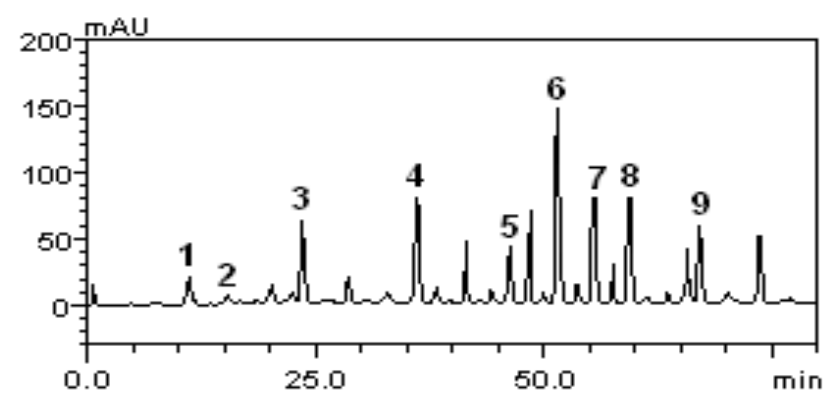

Fig. 5: Representative high performance liquid chromatography profile of ethylacetate extract of C. volubile. Gallic acid (peak 1), catechin (peak 2), caffeic acid (peak 3), rutin (peak 4), quercitrin (peak 5), quercetin (peak 6), kaempferol (peak 7), luteolin (peak 8) and apigenin (peak 9).

\section{CONCLUSION}

The current surge of interest in antioxidant properties of the plants today is due to their possible role as natural additives to replace synthetic ones. Results of the present study showed phenolics, flavonoids and antioxidant capacity, although with different efficiencies. Quercitrin, quercetin, kaempferol, luteolin were the major phenolic compounds in all the extracts of $C$. volubile. Methanol extract exhibited higher potency of free radical scavenging activity and phenolic contents which is highly related to the presence of hydroxyl groups in the phenolic compounds. Thus present data suggest that methanol extract can be used as a good source of natural antioxidants for health benefits and further isolation of bioactive compounds is required for identifying the unknown compounds to establish their pharmacological properties.

\section{Financial support and sponsorship: Nil}

Conflict of interests: The authors declare that there is no conflict of interest.

\section{REFERENCES}

Adefegha SA, Oboh, G. Enhancement of total phenolics and antioxidant properties of some tropical green leafy vegetables by steam cooking. J. Food Proc Preserv, 2011, 35 (5): 615-622.

Adefegha SA, Oboh G, Adefegha OM, Boligon AA, Athayde M.L. Antihyperglycemic, hypolipidemic, hepatoprotective and antioxidative effects of dietary clove (Szyzgium aromaticum) bud powder in a high-fat diet/ streptozotocin-induced diabetes rat model. J Sci Food Agric, 2014, 94: 2726 - 2737.

Adefegha SA, Oboh G, Molehin OR, Saliu JA, Athayde ML, Boligon, AA. Chromatographic Fingerprint Analysis, Acetylcholinesterase Inhibitory Properties and Antioxidant Activities of Redflower Ragleaf (Crassocephalum Crepidioides) Extract. J Food Biochem, 2016, 40 (1); 109-119.

Adefegha SA, Oboh G, Oyeleye SI, Osunmo K. Alteration of starch hydrolyzing enzyme inhibitory properties, antioxidant activities, and phenolic profile of clove buds (Syzygium aromaticum L.) by cooking duration. Food Sci Nutr, 2016, 4 (2): 250-60.

Adesanoye OA, Molehin OR, Delima AA, Adefegha SA, Farombi, EO. Modulatory effect of methanolic extract of Vernonia amygdalina (MEVA) on tert-butyl hydroperoxide- induced erythrocyte haemolysis. Cell Biochem. Funct, 2012, 31: 545-550.

Aline A, Boligon, Janovik V, Boligon AA, Pivetta CR, Pereira RP, Rocha JBT, Athayde, ML.HPLC Analysis of Polyphenolic Compounds and Antioxidant Activity in Nasturtium officinale Int J Food Propert, 2013, 16(1): 61-69.

Barbosa -Filho VM, Waczuk EP, Kamdem JP, Abolaji, AO, Lacerda, SR, Costa, JGM. Phytochemical constituents, antioxidant activity, cytotoxicity andosmotic fragility effects of Caju (Anacardium microcarpum). Ind Crop Prod, 2014; 55, 280-288.

Bhattacharyya A, Chattopadhyay R, Mitra S, Crowe SE. Oxidative Stress: An Essential Factor in

the Pathogenesis of Gastrointestinal Mucosal Diseases Physiol Rev, 2014, 94 (2): 329-354.

Burkill HM, 1985. The Useful Plants of West Tropical Africa, vol. 1,Royal Botanic Gardens, Kew, pp. 319

Chu Y, Sun J, Wu X, Liu, RH. Antioxidant and antiproliferative activity of common vegetables. J Agric Food Chem, 2002, 50: 6910-6916.

Dehpour AA, Ebrahimzadeh MA, Nabavi SF, Nabavi, SM. Antioxidant activity of methanol extract of Ferulaassa foetida and its essential oil composition, Grasas Aceites, 2009, 60 (4): 405-412. 
Duthie G, Duthie S, Kyle J. Plant polyphenols in cancer and heart disease: Implications as nutritional antioxidants. Nutr Res Rev, 2000, 13: 79-106.

Eghdami A., Sadegh F. Determination of total phenolic and flavonoids contents in methanolic and aqueous extract of Achillea millefolium. Org Chem J, 2010, 2: 81-84.

Erukainure OL, Oke OV, Ajiboye AJ, Okafor OY. Nutritional qualities and phytochemical constituents of Clerodendrum volubile, a tropical non-conventional vegetable. Int Food Res J, 2011, 18 (4): 13931399.

Fred-Jaiyesimi A, Adekoya Y. Pharmacognostic studies and antiinflammatory activities of Clerodendrum volubile P. Beauv leaf. Int J Phytomed, 2012, 4: 414-418

Gu R, Wang Y, Long B, Kennelly E, Wu S, Liu B. Prospecting for bioactive constituents from traditional medicinal plants through ethnobotanical approaches. Biol Pharm Bull, 2014, 37(6) :903-915.

Guyot S, Bernillon S, Poupard P, Renard CMGC. 2009. Multiplicity of phenolic oxidation products in apple juices and ciders, from synthetic medium to commercial products, In: Daayf F, Lattanzio V, (Eds.). Recent advances in polyphenol research. UK Wiley Blackwell: pp 278-92.

Gyamfi MA, Yonamin EM, Aniya Y. Free-radical scavenging action of medicinal herbs from Ghana: Thonningia sanguinea on experimentally-induced liver injuries. Gen Pharmacol, 1999, 32: 661-667.

Hemalatha P, Bomzan DP, Sathyendra Rao, BV, Sreerama YN. Distribution of phenolic antioxidants in whole and milled fractions of quinoa and their inhibitory effects on $\alpha$ - amylase and $\alpha$-glucosidase activities Food Chem, 2016, 199: 330-338.

Kasote DM, Katyare SS, Hegde MV, Bae H. Significance of Antioxidant Potential of Plants and its Relevance to Therapeutic Applications. Int J Biol Sci, 2015, 11(8): 982-991.

Mattila P, Hellstrom J. Phenolic acids in potatoes, vegetables, and some of their products. J. Food Compos Anal, 2006, 20: 152-160.

Meda A, Lamien C, Romito M, Millogo J, Nacoulma OG. Determination of the total phenolic, flavonoid and proline contents in Burkina Faso honey, as well as their radical scavenging activity. Food Chem, 2005, 91: 571-577.

Molehin OR., Adefegha SA. Comparative study of the aqueous and ethanolic extract of Momordica foetida on the phenolic content and antioxidant properties. Int Food Res J, 2014, 21(1): 401-405

Molehin OR., Adefegha SA, Oboh G, Saliu JA, Athayde ML, Boligon AA. Comparative study on the phenolic content, antioxidant properties and HPLC fingerprinting of three varieties of celosia species. J Food Biochem, 2014, 389: 575-583.

Moure A, Cruz JM, Franco D, Dominguez JM, Sineiro J, Dominguez H. Natural antioxidants from residual sources. Food Chem, 2001, 72: 145-171

Meir S, Kanner J, Akin B, Hadas SP. Determination and involvement of aqueous reducing compounds in oxidative defense systems of various senescing leaves. J Agric Food Chem, 1995; 43: 1813-1815

Oboh G, Agunloye OM, Adefegha SA, Akinyemi AJ, Ademiluyi, AO. Caffeic and chlorogenic acids inhibit key enzymes linked to type 2 diabetes (in vitro): a comparative study. J Basic Clin Physiol Pharmacol, 2015, 26 (2): 165-170.

Ogunwa TH, Adeyelu TT, Fasimoye RY, Oyewale MB, Ademoye TA, Ilesanmi OC, Awe OB, Ajiboye SA, Oloye BO, Sholanke DR. Phytochemical evaluation and in vitro antioxidant status of Clerodendrum volubile (an indigenous medicinal plant). Pak J Pharm Res, 2016; $2: 77-88$
Oyaizu M. Studies on products of browning reaction: Antioxidative activity of products of browning reaction prepared from glucosamine. Japan J Nutr. 1986, 44: 307-31.

Pavithra K, Vadivukkarasi S. Evaluation of free radical scavenging activity of various extractsof leaves from Kedrostis foetidissima (Jacq.) Cogn Food Sci Human Wellness, 2015, 4: 42-46.

Pereira RP, Fachinetto R., De Souza Prestes A., Puntel RL, Da Silva GN. Antioxidant effects of different extracts from Melissa officinalis, I and Cymbopogon citratus. Neurochem Res, 2009, 34: 973983

Ramjith US, Roopitha B, Jacob CM. Isolation anti-diabetic and antioxidant evaluation of aqueous extract of Cansjera rheedii leaves. Asian J Pharm Clin Res, 2013, 6(3): 228-23

Re R, Pellegrini N, Proteggente A, Pannala A, Yang M, Rice-Evans C. Antioxidant activity; applying an improved ABTS radical cation decolorisation assay. Free Radic. Bio Med, 1999, 26: 1231-1237.

Rice-Evans C, Miller N. Antioxidant property of phenolic compounds. Trends Plants Sci, 1997, 2:152-159

Scalbert A, Manach C, Morand C, Remesy C. Dietary polyphenols and the prevention of diseases. Crit Rev Food Sci Nutr, 2005, 45: $287-306$

Salas PG, Soto AM, Carretero, AS, Gutiérrez, AF. Phenolic Compound-Extraction Systems for Fruit and Vegetable Samples. Mol, 2010, 15: 8813-8826.

Singleton VL, Orthofer R, Lamuela-Raventos RM. Analysis of total phenols and other oxidation substrates and antioxidants by means of Folin-Ciocalteau's reagent, Methods Enzymol, 1999, 299:152-178.

Sultan B, Anwar F. Flavonols (Kampeferol, quercetin, myricetin) contents of selected fruits, vegetables and medicinal plants. Food Chem, 2009,108 (3): 879-884.

Tiwari A. Imbalance in antioxidant defense and human diseases: multiple approach of natural antioxidants therapy. Curr Sci, 2001, 81: 1179-1187.

Wagner C, Fachinetto R, Dalla CL, Corte Brito VB, Severo D. Quercitrin, a glycoside form of quercetin, prevents lipid peroxidation in vitro. Brain Res, 2006, 1107:192-198.

Wong-paz JE, Contrerasr-Esquivel JC, Rodrfguez-Herrera R, CarrilloInungaray RM, Lopez LI, Nevarez-Moorillon GV. Total phenolic content, in vitro antioxidant activity and chemical composition of plant extracts from semiarid Mexican region. Asian Pacific J Trop Med, 2015, 5:104-111

Zar, J.H., 1984. Biostatistical Analysis, Prentice-Hall, Inc., Upper Saddle River, NJ p. 620.

\section{How to cite this article:}

Molehin OR, Oloyede OI, Boligon AA. Comparative study on the phenolic content, antioxidant properties and HPLC fingerprinting of the extracts of Clerodendrum volubile P. Beauv. J App Pharm Sci, 2017; 7 (03): 135-140. 